\title{
Validation of a booklet on language developmental milestones in childhood
}

\author{
Débora de Souza Alexandre ${ }^{1}$ \\ https://orcid.org/0000-0002-4251-0231 \\ Matheus Francoy Alpes ${ }^{1}$ \\ https://orcid.org/0000-0001-9617-7668
}

Ana Claudia Mirândola Barbosa Reis ${ }^{1}$

https://orcid.org/0000-0002-5800-6566

Patrícia Pupin Mandrá

https://orcid.org/0000-0002-2926-0354

Universidade de São Paulo, Faculdade de Medicina de Ribeirão Preto - FMRP-USP, Departamento de Ciências da Saúde, Ribeirão Preto, São Paulo, Brasil.

Research support source: Programa Unificado de Bolsas - Universidade de São Paulo (PUB - USP) and Santander Bank.

Conflict of interests: Nonexistent

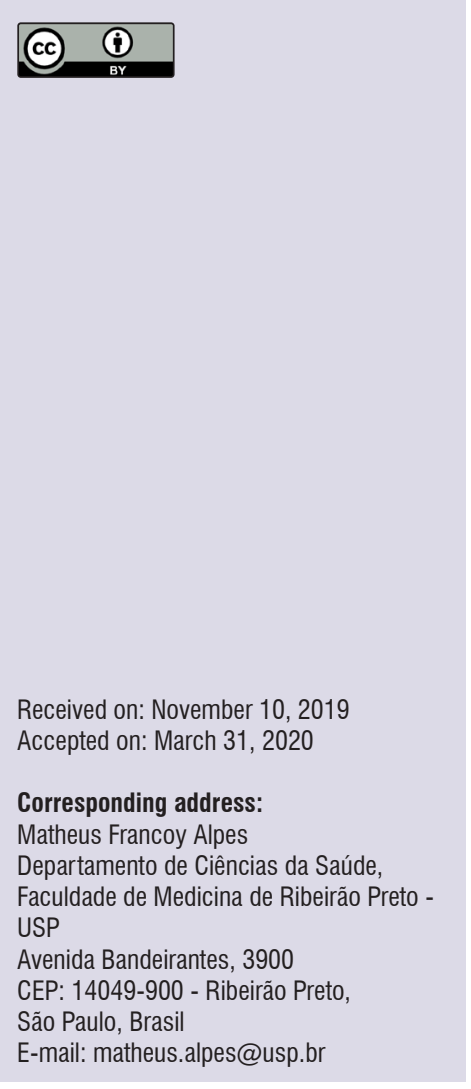

\section{ABSTRACT}

Purpose: to develop and validate the content of printed educative material (booklet) on the typical oral language development.

Methods: methodological development research with content validation. The material was produced following a literature review, in which the available publications approaching this theme were analyzed. The descriptors used were "child language", "child development", "language development", and "language development disorders". A total of 37 judges (specialists in the field and target audience) participated, divided into groups: speech-language-hearing therapists (LJG), educators (EJG), and relatives (RJG). They answered a 5-point Likert-scale instrument. The absolute percentage agreement (APA) and content validity index (CVI) were applied, whose respective minimum values of $75 \%$ and 0.78 were adopted.

Results: the booklet encompassed the aspects of phonology, semantics, syntax, narrative and hearing, citing what is expected for each age. At the end of each topic, suggestions on how to stimulate the child's language were made. The mean $\mathrm{VCl}$ scores were: $\mathrm{LJG}=81.3 \%$, $E J G=93.51 \%$, and $\mathrm{RJG}=89.4 \%$.

Conclusion: the booklet reached a high content and design validity index and will aid health education initiatives, allowing its content to be spread among families and professionals involved in child development.

Keywords: Validation Studies; Language Development; Educative Technology; Health Education; Speech, Language and Hearing Sciences 


\section{INTRODUCTION}

Health education initiatives can lead to the development of new knowledge, as well as changes in behavior and lifestyle ${ }^{1}$, including the motivation to seek health professionals to get more information and learn about possible treatments ${ }^{2}$. This process involves the communication between institutions/professionals and the citizens $\mathbf{s}^{3,4}$, and, in this context, the printed educative technologies - as posters, books, booklets, handouts and/or pamphlets - are widely used resources ${ }^{3,5-9}$.

Printed technology supports and reinforces oral information and/or discussions, serves to offer instructive guidelines in cases of future doubts, and aids in decision-making ${ }^{3-6}$, besides increasing the target audience's autonomy ${ }^{10}$, making it part of the mediation between professionals and the population in the educative process ${ }^{4-12}$

The development of printed educative material must follow certain principles: a) be scientifically based ${ }^{11-14}$; b) have a meta-educational approach to the intended audience ${ }^{15}$; c) be both readable and understandable to the intended audience ${ }^{13,14,16}$; d) be evaluated by judges regarding its content, language, structure, design/ layout, illustrations, and general composition ${ }^{13,14}$. The printed material must be attractive and easy to read; therefore, the vocabulary used must be coherent with the message and target audience ${ }^{16}$. The content must be validated first by specialized judges with expertise in the field and then by the public audience ${ }^{16-18}$.

In the field of neuroscience, language acquisition is one of the classic examples of a critical or sensitive period of development. Studies refer to different temporal windows for learning different language levels. Hence, one learns phonology from birth to the end of the first year of life; syntactical development occurs between the $18^{\text {th }}$ and $36^{\text {th }}$ month of life; and vocabulary has an important lexical boom at the age of 18 months, though acquisition goes on throughout the whole life ${ }^{19}$. Being exposed to language in one's first year of life influences the brain's neural circuits still in the preverbal period, and the development of vocabulary in the first years of life is associated with future academic success ${ }^{20}$. The extension of oral vocabulary at 24 months of age is a predictive factor of the child's academic performance (reading and mathematics) in preschool age ${ }^{21}$.

Following up child language development from birth is extremely important, as the period from 0 to 36 months is essential to linguistic development, and any exposure to risk and/or protection factors can directly affect this process ${ }^{15}$.

Many relatives are uncertain about their children's language development and how to deal with these situations. Many times, they seek a pediatrician's or educator's instruction, although the ideal is that they be referred for a language-expert speech-languagehearing therapist.

A booklet scientifically developed and validated is a very relevant option of an educative instrument to inform the different public - as health professionals, educators, relatives, and other people who have direct contact with the children - about the language developmental milestones. Its importance lies in widely spreading this content to encourage the recognition of delays and the early referral to the speech-languagehearing assessment and intervention processes, thus contributing to the prognosis of different cases.

During practice in different scenarios of supervised internship, in different levels of complexity (as in primary schools, family health care units, and speech-languagehearing diagnosis and intervention specialized centers), many relatives, in the anamnesis, commonly reported having been instructed to wait until the child was five or six years old (the period when language development is completed) to seek help. Thus, considering these facts and the information exposed in the previous paragraphs, the first research question arose: "Is there any scientifically validated printed material to inform about language development from birth to the six years old?". After analyzing the institutional guidelines and informative material from the Municipal and State Departments of Education and Health and the Ministry of Health, no such educative technology was found. Hence, the process of developing the first version of the material was started, which brought about the second research question: "Is the content of this material adequate, according to the specialized judges' evaluation? Is it adequate for the public audience?".

Thus, this study aimed at developing and validating the content of a printed educative technology (booklet) about the typical oral language development to inform and advise relatives, as well as health and education professionals.

\section{METHODS}

This study is a descriptive, methodological development ${ }^{16-18}$ research on the validation of a piece of technology, approved by the Research Ethics Committee of the Ribeirão Preto Clinics Hospital 
under number 1.972.306/2017. All the judges were formally invited to participate and filled out and signed the Informed Consent Form (ICF). All of them were reassured of having their questions answered throughout the study. They were also given the right to interrupt their participation.

\section{Development of the booklet}

The material was developed following the recommendations mentioned in the literature for preparing educative material ${ }^{2,7,11-16,22-25}$. This stage was divided into four phases: 1) literature review, to develop the scientific basis for the content; 2) content organization; 3) Development of the booklet's content, illustrations and layout; and 4) content and design validation.

Terms selected from the list in the Health Sciences Descriptors (DeCS), 2016 version, were employed for the literature review (phase 1), namely: child language; child development; language development; language development disorders; speech-language-hearing sciences; and health education. The search strategy was organized with the support from a librarian, using the OR and AND logical operators to combine the terms. The chosen databases for the search were the Literature in the Health Sciences in Latin America and the Caribbean (LILACS), and the Scientific Electronic Library (SciELO). The scientific articles were selected according to the following inclusion criteria: time of publication (from January 2005 to January 2017); language (published in Portuguese); availability (free full-text electronic access); and, after having read the abstracts, those that clearly mentioned the developmental milestones of the phonological, semantical and syntactical aspects and the narrative function of children who speak Brazilian Portuguese, as well as the protection and risk factors. In the end, 12 references were fully read, having their content registered in a spreadsheet, subsiding the development of the material.

In phase 2, the content was initially organized in a spreadsheet that grouped together all the described developmental milestones by age group and then by language level.

In phase 3, regarding content, the topics were written out, paying special attention to textual cohesion and coherence and adequacy to the current Portuguese orthographical norms. As for the illustrations and layout, the illustrations and watermarks inside the booklet were produced by a graphic design student from the Universidade Estadual Paulista, SP, Brazil, whereas the image on the front and back cover was taken from the Freepik free-access website.

The booklet was developed in the Microsoft Publisher ${ }^{\circledR}$ software. The material was divided into topics (by age group) as follows: a) Newborn to 12 months old; b) 13 to 24 months; c) 2 years and 1 month to 3 years; d) 3 years and 1 month to 4 years; e) 4 years and 1 month to 6 years old. The content was organized in order, encompassing the oral language aspects of phonology, semantics, syntax, narrative and hearing. Information (tips) on attitudes favorable to the child's language and speech development was included at the end of each topic, as well as behaviors to watch out for as risk indicators of this development (Figure 1). 


\section{Dos 13 aos 24 meses}

\section{AOS 18 MESES}

Produz cerca de 50 palavras (as mais usadas na sua rotina) e compreendem ordens simples relacionadas à rotina diária (ex.: "vamos comer"/"pegue a boneca"/ "jogue a bola").

\section{AOS 24 MESES}

A criança fala e/ou usa gestos para expressar suas necessidades, chamar a atenção, informar e

perguntar.

incluindo seu nome, verbos

Aprende cerca de 25 palavras novas por mês

São comuns a ausência de alguns sons (ex.: bola = "boa") ou troca de um pelo outro (ex.: casa = "tasa" sapo = "tapu").

Compreende perguntas, ordens e afirmações rotineiras na presença dos objetos (ex.: "é hora de comer!" - a criança dirige-se a cozinha / "Pega a chave e põe na gaveta" - a criança o faz).

Explora brinquedos levando à boca, jogando, empilhando e chama a atenção para o que está fazendo.

16 aos 21 meses: localiza diretamente todos os sons para os lados, para baixo e para cima.
- Responde e participa de pequenas conversas (diálogo).

- A criança imita situações vivenciadas (ex.: dá banho ou comida para boneca durante a brincadeira).

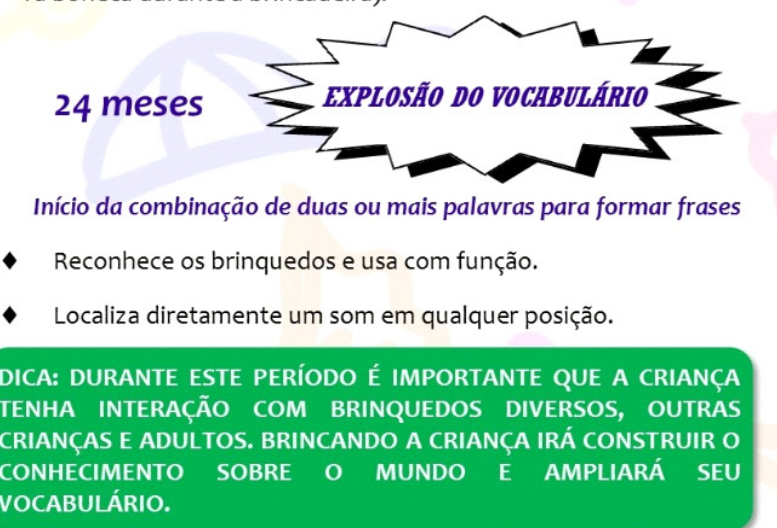
VOCABULÁRIO.

ALERTA: CRIANÇA QUE NÃO PRODUZ FALA ATÉ 2 ANOS DEVE SER AVALIADA POR UM FONOAUDIÓLOGO.

Source: Alexandre, Mandrá, 2017

Figure 1. Content from pages 4 and 5 of the booklet

\section{Educative material content and design validation}

\section{Sample: Judges' eligibility criteria}

The jury of specialized experts (speech-languagehearing judges' group - LJG) comprised eligible speech-language-hearing clinical therapists from two public services and a private clinic, who met the criteria: performing language diagnosis and intervention in children and adolescents, and being employed at the time of the collection. The estimate was for the selection of nine judges, as described in the literature ${ }^{26,27}$, who were identified by the network or snowball sampling ${ }^{16,26}$.

Comprising the jury that represented the target audience, two groups of judges were chosen: one with educators (EJG) from two preschools, nursery school teachers, from the municipality's public and private system; and one with relatives (RJG), involving the family of children and/or adolescents that were waiting in the reception area of an integrated public medium-complexity rehabilitation service. The total estimate was of 15 participants in the LJG, 15 in the RJG, and 30 in the EJG (10 from the public school, and 10 from the private school). It was a convenience, non-probabilistic sample; therefore, only the judges who did not participate to agree, did not reply within schedule and/or returned the instrument without having the required items filled out were excluded.

\section{Collection instrument}

An instrument with close-ended questions in questionnaire format was developed, considering the validation research in the literature $e^{4,5,9,10,13,14,28,29}$. It was divided into blocks: a) content; b) language; c) illustrations; d) layout; and e) motivation (Table 1), adding up to 20 questions with a Likert-type psychometric response scale 16,17,26,28: SD (strongly disagree); D (disagree); NAND (neither agree nor disagree); A (agree); and SA (strongly agree) 
Table 1. Total possible answers by category of scale questions

\begin{tabular}{ll}
\hline Category/Block & Questions \\
\hline & 1. Is the content adequate for the target audience? \\
2. Does the content present relevant information to the target audience? & 3. Are the subtitles relevant? \\
Content & 4. Should the highlighted portions of the text be kept that way? \\
& 5. Is the sequence of the text logical and coherent?
\end{tabular}

Total possible answers in this item $=5$
Language
6 . Is the vocabulary used in the booklet accessible to the target audience?
7. Is the written text clear and objective?

Total possible answers in this item $=2$

8. Are the illustrations necessary to understand the content?

9. Do the illustrations motivate handling the printed material?

Illustration 10. Do the illustrations clarify the content?

11. Is the amount of illustrations adequate to the content of the material?

12. Do the illustrations present lines and/or resolution adequate to the target audience?

Total possible answers in this item $=5$

13. Is the text adequately formatted regarding font type and size?

14. Is the visual layout attractive and organized?

Layout 15. Are the colors adequately chosen?

16. Is the size of the pages adequate?

17. Is the number of pages adequate?

Total possible answers in this item $=5$

\section{Is the content motivating?}

Motivation 19. Did the content get you interested?

20. Did the content answer any doubts on the subject?

Total possible answers in this item $=3$ SCORE TOTAL $=20$

Fonte: Dados da pesquisa.

In the final arrangement, there were three dichotomous (yes/no) questions: 1) "Would you make any change in the content?"; 2) "Would you change the writing of the text in any aspect (vocabulary used)?"; and 3) "Would you make any change in the graphic layout (text organization, images and forms)?". In case the judge marked YES, they could write out their suggestions in a designated place.

The header brought the instructions, explaining that the judge should first read the booklet and then answer the questionnaire. There was a space provided right underneath it to check what group the judge belonged to (LJG or EJG), their date of birth, and time of professional experience; for the RJG, schooling and current occupation were added. After a pretest, the content and vocabulary were adjusted so it could be then applied.

\section{Collection procedure}

After the first version of the booklet was fully developed, e-mails were sent to the speech-languagehearing therapists explaining the purpose of the project, inviting them to participate as content-expert judges and requesting to schedule a meeting to hand them the folder with the research kit, which contained the ICF, the printed version of the booklet, and the questionnaire with instructions. The material stayed in the judges' hands for one to seven days, and then the kits were collected. After data analysis, the booklet was revised and updated for the printing of the second version, whose content had already been validated by the specialists.

Validation by the target audience took place in two stages. In the first one, the second version was 
presented for validation by the EJG. The principals of one public and one private school were contacted for authorization. The educators were approached in the school and those who agreed to participate received the kit - with the ICF, the second version of the printed booklet, and the questionnaire with instructions -, which should be returned within seven days. After this group analyzed the material, the third version of the booklet, with the necessary adjustments, was produced. Then, in the second stage, the mothers who were with their children in the waiting room of a public rehabilitation service were invited to make part of the RJG. In this person-to-person approach, the purpose and procedure of the research were explained (instructions for analyzing the material and answering the questionnaire); then, those who agreed to participate signed the ICF and received the research kit, which contained the third version of the material. The researcher waited there for 45 minutes, on average, to receive the questionnaire back.

\section{Analysis procedure}

The information about the judges was organized in Microsoft ${ }^{\circledR}$ Excel $\AA \quad(2016)$ spreadsheets. The descriptive analysis was made with the calculation of absolute and relative frequencies, in addition to the measures of central tendency (mand and median).

The answers obtained in each block (content, language, illustrations, layout, and motivation) were placed in spreadsheets, one (1) point given to the marked answer and zero (0) to the other items on the Likert scale.

The agreement between judges was defined as the degree in which two or more evaluators, using the same scale, gave equal classification to the same object of analysis $2,7,10-16,28-30$.

Two agreement measures were used: a) absolute percentage agreement (APA), or agreement index (Al); and b) content validity index (CVI). The absolute percentage agreement (APA) is found by calculating the number of times the evaluators agreed and dividing it by the total number of evaluations, and then multiplying the result by 100 to obtain the percentage. The minimum agreement value considered was $75 \%{ }^{26,29}$. The CVI was applied to measure the degree of agreement between the judges for each one of the items comprising the blocks of the instrument (Table 1). The number of answers marked in the agreement scale ( 4 and 5 - agree and strongly agree) was divided by the total number of answers ${ }^{10,27}$. The cutoff score employed for the CVI was 0.78 , for both each answered item and the questionnaire as a whole?

\section{RESULTS}

Throughout the process, three versions of the material were developed, which were revised regarding its content and design, until the final version was validated. Table 2 shows the content that was selected after the literature review to compose the first version of the booklet.

Table 2. Content selected to comprise the first version of the booklet after the literature review

\begin{tabular}{ll}
\hline \multicolumn{1}{c|}{ Age } & \multicolumn{1}{c}{ Content } \\
\hline & - From the first day to the first month of life, the infants have in crying their reaction to pain and hunger; they wake up and startle with unfamiliar \\
& sounds. \\
& - From 2 to 3 months old, crying becomes different in each situation (hunger, pain or fussiness); babbling and chuckling seem to be related to the \\
& sensation of well-being, they react to human speech; they chuckle, gaze and babble. \\
$0-12$ months & - By the 5th month, they start playing with their voice and the sounds they utter, repeating a syllable over and over (e.g.: /papapa/, /mamama/). \\
& - From 8 to 9 months old, intentional communication behaviors appear; they repeat sounds uttered by others; \\
& - The first words appear when they are 10 to 15 months old; short words are acquired before the long ones; \\
- They can repeat words said by others, but the repetition will not follow the same phonetic pattern (e.g.: "Where's the dog?" - the child: [daw]).
\end{tabular}


- 18 months: expanding of their phonological system, broadening their phonetical inventory; period characterized by the occurrence of sound substitutions and omissions.

- They present a functional language, i.e., they communicate to express their needs, call attention, inform and ask.

- They speak isolated words or word-like sentences. (e.g.: [memilk] - "I want milk").

- They produce onomatopoeias (e.g.: [ow-ow] for dogs), idiosyncratic words, i.e., the child's own words (e.g..:[ashunk] for elephant), contextual words (ex.: [mehungry] - when they want to eat), and social words (ex.: [dis] - when they are pointing at something.

13-24 months - From 18 to 22 months, they produce about 20 words and understand about 50.

- They maintain a conversation by speculating and complementing.

- They understand routine and situational questions, orders and statements (e.g.: "It's time to eat!" - the child goes to the kitchen).

- Beginning at 18 months old, two- or three-word sentences are produced (ex.: [moh milk] for "I want more milk").

- They understand routine and situational two-command orders (e.g.: "Pick up the key and put it in the drawer" - the child does so).

- By the end of the second year of life, the so-called vocabulary boom takes place.

- All phonological simplifications are expected.

- Elimination of the processes of syllable deletion, assimilation, fricative stopping, velar backing and fronting, and liquid reduction (by 3 years and 6 months old).

- /s/ is acquired by 2 years and six months old; /s/ is most commonly substituted by $/ \mathrm{J} /$.

- By 2 years old, children can produce more than 200 words, and by 2 years and 6 months old, more than 500 words.

- From 2 years to 2 years and 6 months old, sentences have 3 or 4 words, with incorrect nominal and verbal inflections (e.g.: "It's mine ball"; "She eat all cookie").

- They do not properly use the genders of the personal pronouns (you, I, he/she), possessives (my) and demonstratives (this) (e.g.: "Sally is wearing his daddy's shoes").

2 years and - Close to three years old, coordination between sentences is noticed (e.g.: "This doll cries and pees").

1 month to 3 - They use many nouns: names of toys, objects around the house, people they daily live with, parts of the body (at least 4), food, animals, drinks, years clothes, some categories (toy, food, animal). They use many verbs to represent actions, as well as some adjectives (big/small, clean/dirty, ugly/ pretty, hot/cold). Semantic deviations are frequent in words with lexical meaning (super-extension, sub-extension, antonymy).

- The prepositions appear: "of", indicating possession, "for" indicting beneficiary (e.g.: "house of grandma").

- They say and understand some adverbs of place (there, here, inside, near) and pronouns (I, you, me, mine, he, this). They refer to time with some adverbs, as "now" and "yesterday", but they use unsteadily.

- They understand and verbally answer questions with the pronouns where, who, what (e.g.: "Where is the doll?").

- They use oral language to ask (to meet their physical and psychological needs), inform, question, interact.

- They narrate, helped by the other's questions, about the place (where), the happenings (what), and people (who). Proto-narrative sentences.

- They talk with people in familiar contexts about concrete subjects with present time referential, in simple turns (one sentence with the minimal necessary information so the conversation will not be interrupted).

- The adult is the model of the developing child's future narratives.

- By three years old, children can classify the same objects in different categories, revealing the same flexibility the adults have when using such categories for inductive inferences.

- Simple and compound six-word sentences are used (coordinated and subordinated with "why" and "but") (e.g.: "I don't wanna eat because it's bad").

- Interrogative clauses appear, with the pronouns "who" and "which" (e.g.: "Which one you want?").

- They make use of verb tenses and grammatical constructions in the present, past and future, though there are incorrect verbal inflections due to rule generalization (e.g.: "Daddy is gonna by me" - future grammatical construction; "He buyed me a candy" - He bought me a candy).

- They use definite articles, respecting gender inflection rules (in Portuguese) (as for number, they can be used by cultural influence) (e.g.: "Gimme the ball and the clown").

- By 3 years and 6 months old, these disappear: non-lateral /R/ liquid simplification, by reduction (e.g.: [wabbit] - rabbit), substitution (e.g.: [twy] - try), or semi-vocalization (ex: [purty] - pretty).

- By 4, these disappear: final consonant simplification (final liquid/r/), by reduction (e.g.: [ka] - car; [maket] - market), or semi-vocalization (e.g.: [play] - pray).

3 years and - Vocabulary: from 500 to 1000 words.

1 month to 4

- Increased meaning of names, verbs and adjectives, including words that refer to feelings (afraid, sad, happy), parts of the body (at least 6), comparison (same/different). All types of semantic deviations are very common (e.g.: "The wolf blew big" - strong).

- They acquire the prepositions "in", "on", "with" indicating companionship.

- They refer to many adverbs of place (over/under, behind/in front of, inside/outside, near/far), but make mistakes when distinguishing opposites. They use and understand the adverbs of time "now/later" but are unsteady when using the other adverbs (e.g.: "Now I'm gonna sleep", "Later I'm gonna play").

- They understand two unrelated orders (e.g.: "Close your closet and bring the ball").

- They understand and verbally answer questions with the pronouns "how" and "when" (e.g.: "How do I take a shower?").

- They ask for things, name things, complain, ask questions about an absent referential, use social expressions to interact. Predominant function: informative.

- They report immediate experiences, i.e., those that are happening at the moment they are asked. When telling stories, they have a hard time being coherent and cohesive, they omit secondary elements and include untrue facts. This is the phase of primitive narratives.

- Regarding conversational skills, what they say is intelligible and coherent with what was previously said. They keep the conversation going more than starting one, present more simple than expansive turns (they talk with more than one clause, with more information than necessary, so the conversation will not stop). If they are not understood, they do not correct themselves; instead, they repeat exactly what they had said. 


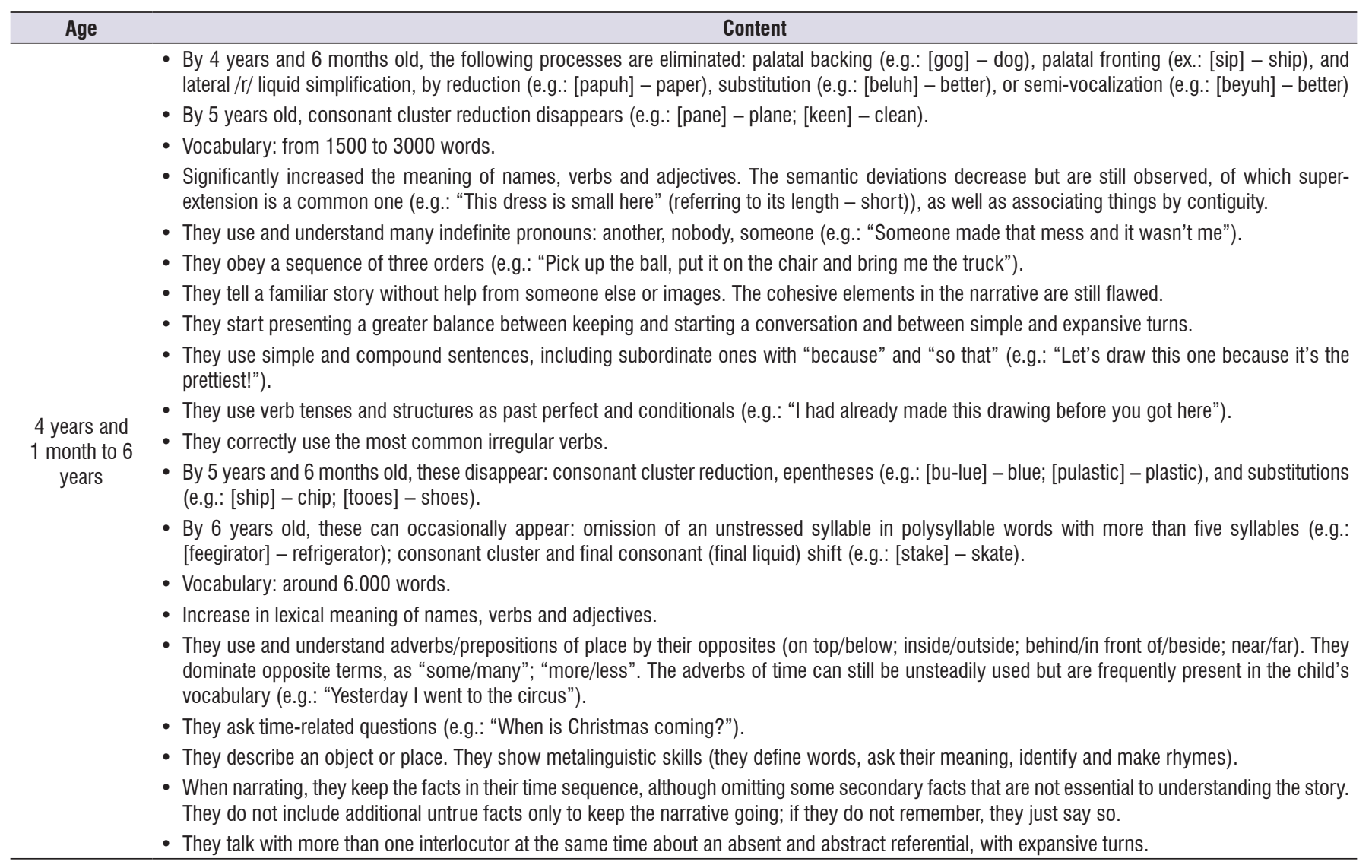

Source: Research data

\section{Validation of the booklet}

The LJG comprised nine speech-language-hearing therapists from a medium-complexity public service and two from a private clinic, who had graduated from college, on average, 7 years and 6 months before. In the EJG, there were 17 educators, six from the public school and 11 from the private one; they had graduated from college, on average, 10 years and 6 months before. The mean age in the RJG was 38 years, and $66 \%$ had finished high school; the two judges who had not finished middle school were capable of reading and writing fluently. Table 3 shows all judges' schooling.

Table 3. Judges' schooling by group

\begin{tabular}{|c|c|c|c|c|c|c|c|c|}
\hline \multirow{3}{*}{ Schooling } & \multicolumn{8}{|c|}{ Groups } \\
\hline & \multicolumn{2}{|c|}{ LJG } & \multicolumn{2}{|c|}{ EJG } & \multicolumn{2}{|c|}{ RJG } & \multicolumn{2}{|c|}{ Total } \\
\hline & $\mathbf{N}$ & $\%$ & $\mathbf{N}$ & $\%$ & $\mathbf{N}$ & $\%$ & $\mathbf{N}$ & $\%$ \\
\hline Unfinished middle school & 0 & 0 & 0 & 0 & 2 & 22.2 & 2 & 5.4 \\
\hline Finished high school & 0 & 0 & 0 & 0 & 6 & 66.7 & 6 & 16.2 \\
\hline Finished higher education & 8 & 72.7 & 17 & 100 & 1 & 11.1 & 26 & 70.3 \\
\hline Doctor's degree & 3 & 27.3 & 0 & 0 & 0 & 0 & 3 & 8.1 \\
\hline
\end{tabular}

Legend: $L J G$ = speech-language-hearing judges' group; $E J G$ = educator judges' group; RJG = relative judges' group.

Source: Research data 
The illustration block, comprising five criteria, achieved mean $\mathrm{CVI}$ of 0.66 , below the expected (Table 4), which was the only block with two "disagree" answers marked. Hence, after the modification suggestions had been analyzed, the illustrations were revised; moreover, some diagrams were included to call the reader's attention to the most important aspects of the chronological period. As for the content block, whose CVI was 0.90 (Table 4), the experts suggested that some items be excluded, and the written language, illustrations and layout be adapted (see Figure 2). It should be highlighted that in the other criteria the options "disagree" and "strongly disagree" were not marked.

Table 4. Distribution of the expert judges' analyses (CVI mean values) by criteria

\begin{tabular}{|c|c|c|c|}
\hline \multirow{2}{*}{ Block } & \multirow{2}{*}{ Items } & \multicolumn{2}{|c|}{ LJG } \\
\hline & & $\%$ & CVI \\
\hline \multirow{5}{*}{ Content } & 1) Is the content adequate for the target audience? & 90.9 & 0.90 \\
\hline & 2) Does the content present relevant information to the target audience? & 100 & 1 \\
\hline & 3) Are the subtitles relevant? & 90.9 & 0.90 \\
\hline & 4) Should the highlighted portions of the text be kept that way? & 81.8 & 0.81 \\
\hline & 5) Is the sequence of the text logical and coherent? & 90.9 & 0.90 \\
\hline Block CVI & mean & & \\
\hline \multirow{2}{*}{ Language } & 6) Is the vocabulary used in the booklet accessible to the target audience? & 81.8 & 0.81 \\
\hline & 7) Is the written text clear and objective? & 81.8 & 0.81 \\
\hline Block CVI & mean & \multicolumn{2}{|c|}{0.81} \\
\hline \multirow{5}{*}{ Illustration } & 8) Are the illustrations necessary to understand the content? & 63.3 & 0.63 \\
\hline & 9) Do the illustrations motivate handling the printed material? & 63.3 & 0.63 \\
\hline & 10) Do the illustrations clarify the content? & 54.5 & 0.54 \\
\hline & 11) Is the amount of illustrations adequate to the content of the material? & 72.7 & 0.72 \\
\hline & $\begin{array}{l}\text { 12) Do the illustrations present lines and/or resolution adequate to the target } \\
\text { audience? }\end{array}$ & 81.8 & 0.81 \\
\hline Block CVI & mean & \multicolumn{2}{|c|}{0.66} \\
\hline \multirow{5}{*}{ Layout } & 13) Is the text adequately formatted regarding font type and size? & 81.8 & 0.81 \\
\hline & 14) Is the visual layout attractive and organized? & 90.9 & 0.90 \\
\hline & 15) Are the colors adequately chosen? & 72.7 & 0.72 \\
\hline & 16) Is the size of the pages adequate? & 90.9 & 0.90 \\
\hline & 17) Is the number of pages adequate? & 90.9 & 0.90 \\
\hline Block CVI & mean & \multicolumn{2}{|c|}{0.84} \\
\hline \multirow{3}{*}{ Motivation } & 18) Is the content motivating? & 90.9 & 0.90 \\
\hline & 19) Did the content get you interested? & 90.9 & 0.90 \\
\hline & 20) Did the content answer any doubts on the subject? & 63.3 & 0.63 \\
\hline Block CVI & mean & & \\
\hline CVI & Total & & \\
\hline
\end{tabular}

Legend: $L J G=$ speech-language-hearing judges' group; $C V I=$ content validity index 


\section{Suggested modifications}

- Revise repetitive content and correct chronology in the syntactical plane (p.13 and 18);

- Rewrite sentences to make the text more objective and less extensive;

- Reduce the number of pages and summarize content by age milestone;

- Correct grammar mistakes and either replace technical terminology by common usage vocabulary or explain it;

- Include information on the work of speech-language-hearing therapists and when to seek their professional help;

- Add diagrams and/or concept maps and use more explanatory illustrations;

- Use a lighter background color and watermark.

Source: Research data

Figure 2. Modifications suggested by the expert judges after evaluating the first version

The mean CVI values, following the evaluation of the second version of the educative material by the target audience group of judges, are presented in Table 5.

It is noted that the mean CVI of the illustration block was within cutoff limits, established at 0.78 , whereas the other criteria were over 0.90 , indicating that content, language, layout and motivation achieved a great level of agreement.

It was also noted that the general mean CVI score per question was $0.80 \%$ (by the LJG), $0.93 \%$ (by the EJG), and $0.90 \%$ (by the RJG) (Tables 4 and 5). Therefore, there was a high level of agreement between expert and target audience judges, enabling the third version of the booklet to have its content and design validated.

The absolute percentage agreement (APA) of the whole booklet reached the value of $98.45 \%$, which is above the minimum established for acceptance in this study $(75 \%)^{26}$ and considered among evaluators a high agreement value.

It should be emphasized that the booklet was evaluated by content judges (experts) and target audience judges. The final validated version, which included the suggested changes, was printed in the A4 format (sheets of 29,7 $\times 21 \mathrm{~cm}$ ), with front and back cover, and containing 23 pages. Of these, 11 had their content distributed by topic (by age group), as follows: a) newborn to 12 months; b) 13 to 24 months; c) 2 years and 1 month to 3 years; d) 3 years and 1 month to 4 years; and e) 4 years and 1 month to 6 years. It was orderly arranged, encompassing the aspects of phonology, semantics, syntax, narrative, and hearing, based on the literature reviewed. Tips on how to stimulate the child's language, as well as behaviors to watch out for as indicators of risk to language development, were added at the end of each topic. On page 12 , there is information about the speech-languagehearing therapists' work and how to find help from them. On pages 13 to 21 , tables are summarizing the main age milestones and evolutive behaviors, with the following titles: Hearing; Speech Sounds; Speaking Words; Speaking Sentences; Telling Stories. In the end, there were two pages with bibliographical references. An example of how the pages were designed is presented in Figure 3. 
Table 5. Distribution of the number of agreements (CVI mean values) between target audience judges

\begin{tabular}{|c|c|c|c|c|c|}
\hline \multirow{3}{*}{ Block } & \multirow{3}{*}{ Items } & \multicolumn{4}{|c|}{ Judges } \\
\hline & & \multicolumn{2}{|c|}{ EJG } & \multicolumn{2}{|c|}{ RJG } \\
\hline & & $\%$ & CVI & $\%$ & CVI \\
\hline \multirow{5}{*}{ Content } & 1) Is the content adequate for the target audience? & 100 & 1 & 100 & 1 \\
\hline & 2) Does the content present relevant information to the target audience? & 100 & 1 & 100 & 1 \\
\hline & 3) Are the subtitles relevant? & 100 & 1 & 100 & 1 \\
\hline & 4) Should the highlighted portions of the text be kept that way? & 100 & 1 & 77.7 & 0.77 \\
\hline & 5) Is the sequence of the text logical and coherent? & 94.1 & 0.94 & 100 & 1 \\
\hline Block CVI & mean & \multicolumn{2}{|c|}{0.99} & \multicolumn{2}{|c|}{0.95} \\
\hline \multirow[b]{2}{*}{ Language } & 6) Is the vocabulary used in the booklet accessible to the target audience? & 94.1 & 0.94 & 100 & 1 \\
\hline & 7) Is the written text clear and objective? & 94.1 & 0.94 & 88.8 & 0.88 \\
\hline Block CVI & mean & \multicolumn{2}{|c|}{0.94} & \multicolumn{2}{|c|}{0.94} \\
\hline \multirow{5}{*}{ Illustration } & 8) Are the illustrations necessary to understand the content? & 70.5 & 0.70 & 88.8 & 0.88 \\
\hline & 9) Do the illustrations motivate handling the printed material? & 88.2 & 0.88 & 77.7 & 0.77 \\
\hline & 10) Do the illustrations clarify the content? & 82.3 & 0.82 & 66.6 & 0.66 \\
\hline & 11) Is the amount of illustrations adequate to the content of the material? & 82.3 & 0.82 & 66.6 & 0.66 \\
\hline & $\begin{array}{l}\text { 12) Do the illustrations present lines and/or resolution adequate to the target } \\
\text { audience? }\end{array}$ & 82.3 & 0.82 & 77.7 & 0.77 \\
\hline Block CVI & mean & \multicolumn{2}{|c|}{0.80} & \multicolumn{2}{|c|}{0.75} \\
\hline \multirow{5}{*}{ Layout } & 13) Is the text adequately formatted regarding font type and size? & 94.1 & 0.94 & 100 & 1 \\
\hline & 14) Is the visual layout attractive and organized? & 100 & 1 & 77.7 & 0.77 \\
\hline & 15) Are the colors adequately chosen? & 94.1 & 0.94 & 88.8 & 0.88 \\
\hline & 16) Is the size of the pages adequate? & 100 & 1 & 100 & 1 \\
\hline & 17) Is the number of pages adequate? & 94.1 & 0.94 & 88.8 & 0.88 \\
\hline Block CVI & mean & \multicolumn{2}{|c|}{0.96} & \multicolumn{2}{|c|}{0.90} \\
\hline \multirow{3}{*}{ Motivation } & 18) Is the content motivating? & 100 & 1 & 88.8 & 0.88 \\
\hline & 19) Did the content get you interested? & 100 & 1 & 100 & 1 \\
\hline & 20) Did the content answer any doubts on the subject? & 100 & 1 & 100 & 1 \\
\hline Block CVI & mean & & 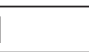 & & \\
\hline CVI & Total & & 93 & & \\
\hline
\end{tabular}

Legend: $L J G=$ speech-language-hearing judges' group; $E J G$ = educator judges' group; RJG = relative judges' group. $C V I=$ content validity index Source: Developed by the author 


\section{Recém-nascido a 12 meses}

A linguagem oral (fala) é importante para o aprendizado e integração da criança no ambiente familiar, escolar e social. Estima-se que em 3 a $15 \%$ da população infantil poderá ocorrer alterações de linguagem e/ou fala e/ou escrita.

Primeiro mês o choro é a reação inicial ao desconforto e à fome.

O recém nascido acorda e assusta-se com sons fortes e produz sons.

2 aos 4 meses: chora de modo diferente para cada situação.

3 meses ocorre o sorriso social. Reage à fala e a voz materna (ou cuidador).

Até 4 meses: produz sons (vogais) e risos que parecem estar relacionados a sensações de bem estar.

3 aos 4 meses: pode começar a virar a cabeça lentamente em direção a um som.

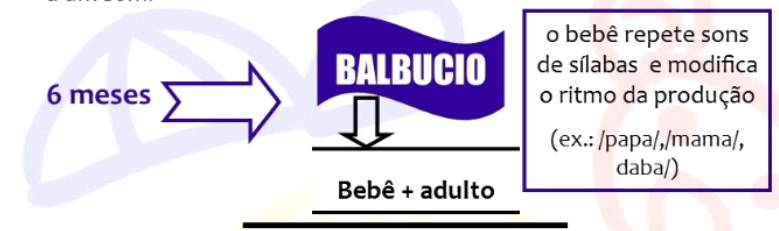

02

Semelhante a uma conversa

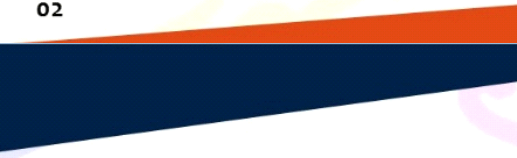

7 meses: localiza o som apenas para um lado.

8 meses: comunica-se com intenção, solicita e responde com gestos indicativos e simbólicos associados ou não a produção de sonsRealiza gestos como social "dar tchau" ou "mandar beijo".

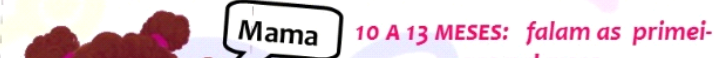
ras palavras ค G Geralmente são os nomes de pessoas e objetos de sua casa (ex.: "boa" para nomear bola". "ma" para mamãe), começam a produzir onomatopeias (ex.: "auau" para cachorro). Repetem palavras ditas pelos outros, de forma igual ou diferente do adulto (ex.: vai dormir... a criança: "mimi”).

12 meses já localiza sons diretamente para os lados e para baixo. Responde ao chamado do nome.

DICA: É MUITO IMPORTANTE O CONTATO VISUAL E INTERAÇÃO COM A CRIANÇA, DANDO SIGNIFICADO AS SUAS AÇÕES.

ALERTA: SE A CRIANÇA NÃO RESPONDE A SONS ALTOS E DE FALA E NÃO PRODUZ SONS ATÉ 8 MESES.

PROCURE UM FONOAUDIÓLOGO

Source: Alexandre, Mandrá, 2017

Figure 3. Example of page arrangement

\section{DISCUSSION}

The educative material is an effective method to aid in the health teaching/learning process ${ }^{25-29}$, which can increase the autonomy of the target audience, as well as of the professionals who work with them, leading to better conducts ${ }^{30}$.

The booklet validated through this study will help families and other health and education professionals - who are in contact with 0- to 6-year-old children monitor their language development and be able to identify the delayed milestones. Once identified, the adult responsible for the child will be encouraged to seek professional help from a speech-languagehearing therapist to get the diagnosis and treatment, if it is the case.

When the parents are uncertain about their children's language development and how to deal with it, it is essential to refer them to a language-specialized speech-language-hearing therapis ${ }^{30}$. However, the guidelines and institutional informative material from the Municipal Departments of Education and Health and the Ministry of Health were analyzed, and no specific educative material in the format of printed booklet dealing with the issue of child language development from birth to six years old was found, as was the target audience intended in this study. The educative material in the printed format is easy to handle and is meant to be taken home, which reinforces the instructions and answers doubts whenever necessary. The role of the written material includes reinforcing the orally-given information and discussion, as well as aiding in cases of future doubts and decision-making ${ }^{29}$.

The written material has advantages for unschooled, little schooled and/or illiterate people, as long as in the planning process mechanisms are used to overcome the barriers to understanding the messages and strategies that encourage the target audience to start using the booklet, and keep them interested in using the educative material. The use of simple language and/or pictographic resources that convey a culturally-relevant message can diminish the communication difficulties, making it more effective and giving it further outreach ${ }^{29}$. Moreover, the judges' agreement per question - which ranged from $70.27 \%$ to $100 \%$, with a mean agreement score of $88.45 \%$, significantly over the minimum value established at $75 \%^{29}$ - makes evident that the content was clearly conveyed to the target audience. Hence, it promoted their understanding of the information regarding its technical and didactic-pedagogical 
aspects, eliminating (or decreasing) the possibility of erroneous interpretations.

The mean CVI values (Tables 4 and 5) for the criteria comprising the content, language, layout and motivation blocks indicate that the experts and the target audience considered the information in the booklet relevant, and the validation by the target audience was extremely important for this technology to be used as a health education tool. The target audience considered the content motivating (CVI of 1 for EJG, and 0.96 for RJG, as seen in Table 5) and the language adequate (CVI 0.94 for both groups - Table 5). Such a positive evaluation is important for the material to be used as a means of conveying information since the booklet was thought of and developed to be an instrument to spread the content on child language development. The scientific validation by the target audience ${ }^{16-18}$ adds credibility to the technology since it states that the tool is adequate to mediate educative initiatives.

The illustrations (drawings, images, photographs, symbols) are very important for the text's readability and understandability, with the role of calling the readers' attention, raising and keeping their interest in reading it, and adding and substantiating information. The layout and design make the reading easier and the material more attractive to the reader ${ }^{5}$. The items that had the lowest CVI values (Table 4) were precisely those related to illustrations in the first version of the booklet. Thus, based on the experts' suggestions, an adjustment process was undertaken to make the illustrations and images informative, self-explanatory, and related to the content exposed in the written text. Many papers on validation of educative materials report that this adaptation process following the judges' analysis is essential to adjust the technology not only in its design but also in content and scientific rigor ${ }^{16,17,26}$. This critical analysis was essential to improve the new version of the material, which would be handed to the public target.

\section{CONCLUSION}

The educative material was developed as a booklet, dealing with the main milestones of typical child language (phonology, semantics, syntax and narrative) and hearing development. Its validation by the different groups of judges (speech-language-hearing therapists, preschool educators, and the children's and adolescents' relatives) revealed it to be a useful, reliable, effective and valid instrument or tool in health education, characterizing it as a facilitator in spreading this information to families and health and education professionals.

\section{ACKNOWLEDGMENT}

Gratitude is extended to the Pró-reitoria de Cultura e Extensão da Universidade de São Paulo (USP) and to the Santander Bank for the grant provided for the development, printing and distribution of the final product.

\section{REFERENCES}

1. Viero VSF, Farias JM. Educational actions for awareness of a healthier lifestyle in adolescents. J. Phys. Educ. 2017;(28):12-28.

2. Silva GG, Carcereri DL, Amante CJ. Estudo qualitativo sobre um programa de educação em saúde bucal. Cad. Saúde Colet. 2017;25(1):7-13.

3. Marins BR, Araujo IS. Materiais educativos de vigilâncias sanitárias: perfil de produção e circulação no tema dos alimentos. Trab. Educ. Saúde. 2016;14(1):137-54.

4. Freitas FV, Rezende Filho LA. Communication models and use of printed materials in healthcare education: a bibliographic survey. Interface Comunic, Saude, Educ. 2011;15(36):243-55.

5. Silva HL, Bezerra FHG, Brasileiro IC. Avaliação de materiais educativos direcionados para o desenvolvimento neuropsicomotor da criança. Rev Bras Promoç Saúde. 2017;30(3):1-6.

6. Moura DJM, Moura NS, Menezes LCG, Barros AA, Guedes MVC. Construção de cartilha sobre insulinoterapia para crianças com diabetes mellitus tipo 1. Rev. Bras. Enferm. 2017;70 (1):7-14.

7. Costa TL, Souza OMV, Carneiro HÁ, Netto CC, Pegonaro-Krook MI, Dutka JCR. Multimedia material about velopharynx and primary palatoplasty for orientation of caregivers of children with cleft lip and palate. CODAS. 2016;28(1):10-6.

8. Campos K, Maximino L, Oliveira JRM, PardoFanton CS, Blasca WQ. Analysis of informative material stored in DVD in the hearing aid adaptation of elderly users. Audiol Commun Res. 2014;19(4):367-74.

9. Reberte LM, Hoga LAK, Gomes ALZ. O processo de construção de material educativo para a promoção da saúde da gestante. Rev Latino-Am Enfermagem. 2012;20(1):1-7.

10. Carvalho RM, Meirelles RMS. Ensino de ciências e saúde para idosos: uma proposta de construção 
de Cartilha Informativa em Grupos de Convivência. Rev. Práxis. 2009;2(1):9-21.

11. Teixeira E, Martins TDR, Miranda PO, Cabral BG, Silva BAC, Rodrigues LSS. Educational technology on potpartum care: development and validation. Rev Baiana Enferm. 2016;30(2):1-10.

12. Demir F, Ozsaker E, Ilce AO. The quality and suitability of written educational materials for patients. The Authors. Journal compilation _ 2008 Blackwell Publishing doi: 10.1111/j.1365-2702.2007.02044.x

13. Sousa CS, Turrini RNT. Validação de constructo de tecnologia educativa para pacientes mediante aplicação da técnica. Delphi Acta Paul Enferm. 2012;25(6):990-6.

14. Oliveira SC, Lopes MVO, Fernandes AFC. Construção e validação de cartilha educativa para alimentação saudável durante a gravidez. Rev. Latino- Am Enfermagem. 2014;22(4):611-20.

15. Mousinho R, Schimid E, Pereira J, Lyra L, Mendes L, Nóbrega V. Aquisição e desenvolvimento da linguagem: dificuldades que podem surgir neste percurso. Rev Psicopedag. 2012;25(78):297-306.

16. Hortense FLP, Bergerot CD, Domenico EBL. Construction and validation of clinical contents for development of learning objects. Rev Bras Enferm. 2018;71(2):306-13.

17. Sabino LM, Ferreira AM, Joventino ES, Lima FE, Penha JC, Lima KF et al. Elaboration and validation of a reader on childhood diarrhea prevention. Acta Paul Enferm. 2018;31(3):233-9.

18. Nascimento TG, Teixeira E. Educational technology to mediate care of the "kangaroo family" in the neonatal unit. Rev Bras Enferm. 2018;71(Suppl 3):1290-7.

19. Kuhl P. Brain mechanisms in early language acquisition. Neuron. 2010;67(5):713-27.

20. Asaridou SS, Demir-Lira OU, Goldin-Meadow S, Small SL. The pace of vocabulary growth during preschool predicts cortical structure at school age. Neuropsychologia. 2017;98(1):13-33.

21. Leite SS, Áfio ACE, Carvalho LV, Silva JM, Almeida PC, Pagliuca LMF. Content Validation Instrument in Health. Rev Bras Enferm. 2018;71(suppl 4):1732-8.

22. Viana LR, Barreto MM, Girard CCP, Teixeira E. Tecnologia educacional para mediar práticas educativas sobre alimentação complementar na Amazônia: estudo de validação. RIST. 2018;28(01):29-40.
23. Jesus EB, Esteves AVF, Teixeira E, Medeiros HP, MH Nascimento, Saboia VM. Validation of educational technology on phototherapy to guide family members of icteric neonates. Rev enferm UERJ. 2018;26:e21789.

24. Santiago JCS, Moreira TMM. Booklet content validation on excess weight for adults with hypertension. Rev Bras Enferm. 2019;72(1):102-8.

25. Lima ACMACC, Bezerra KC, Sousa DMN, Rocha JF, Oriá MOB. Development and validation of a booklet for prevention of vertical HIV transmission. Acta Paul Enferm. 2017; 30(2):181-9.

26. Moreira S, Oliveira TC, Ribeiro LCC, De Paula FA. Construction and validation of manual on Burnout in teachers. Revista de Enfermagem do CentroOeste Mineiro. 2017;7:e1317.

27. Ferreira AS, Almeida CTG, Almedia TG, Vasconcelos EL, Lopes RF, Trindade RFC. Validation of an educational material as pedagogical tool on sexual initiation for teens. Rev enferm UFPE. 2016;10(5):4412-5.

28. Teles LMR, Oliveira AS, Campos FC, Lima TM, Costa CC, Gomes LFS et al. Development and validating and educational booklet for childbirth companions. Rev. esc. enferm. USP. 2014;48(6):8-14.

29. Alexandre NMC, Coluci MZO. Validade de conteúdo nos processos de construção e adaptação de instrumentos de medida. Ciênc. saúde coletiva. 2011;16(7):3061-8.

30. Crestani AH, Oliveira LD, Vendruscolo JF, RamosSouza AP. Specific Language Impairment: the relevance of initial diagnosis. Rev. CEFAC. 2013;15(1):228-37. 